\title{
Women in Micro and Small Business Enterprises and their Financial Cruxes in Ethiopia: A Case Study of Mettu Town
}

\author{
http://doi.org/10.21272/fmir.5(1).98-115.2021
}

\section{S.N. Singh}

Dr, Associate Professor of Economics and Law in the Department of Economics, Faculty of Business and Economics, Mettu University, Mettu, Ethiopia

\begin{abstract}
Ethiopia is fast growing economy among countries in the continent of Africa and the participation of skilled women in the small business enterprises has become interesting for the analysis come across. The role of education of women is the crucial one, especially for third world countries like Ethiopia. Thus, the main purpose of this study is to investigate the participation of skilled women in Micro \& Small Enterprises in case of Mettu town. This study has attempted to portray participation of educated women in Micro and Small Enterprises in the study area. To conduct this study, the data has been collected from both primary and secondary sources. The primary sources of data obtained through structured questionnaire, interviews and observations however the secondary sources of data are books, journals and different written documents of government as well as NGOs. Descriptive method of statistics has been used to analyze the data. The findings of the study reveal that despite of financial crunches the participation of women particularly skilled in MSEs gradually increasing over the period of time in town. Educated women are more likely preferring service sector followed by trade sector in the study area.
\end{abstract}

Keywords: skilled women, micro and small business enterprises, financial cruxes, NGOs and entrepreneurship JEL Classification: G 20, G21 M and M10.

Cite as: Singh, S.N. (2021). Financial Cruxes in Ethiopia: A Case Study of Mettu Town. Financial Markets, Institutions and Risks, 5(1), 98-115. http://doi.org/10.21272/fmir.5(1).98-115.2021

Received: 8 February 2021

Accepted: 10 March 2021

Published: 30 March 2021

Copyright: (C) 2021 by the author. Licensee Sumy State University, Ukraine. This article is an open access article distributed under the terms and conditions of the Creative Commons Attribution (CC BY) license (https://creativecommons.org/licenses/by/4.0/)

\section{Introduction}

1. Background of the study. Throughout history, it has been witnessed that whatever domination and suppression existed, people formed all sorts of means to break chains of the domination. The struggle for women's equal right and for their full participation in all forms of decision-making mechanisms is not an exception (Embet, 2009).

Women for centuries have been voicing their concerns about legislation government policies, traditional customers and religious beliefs which have been instrumental to bring women subordinate sets. Despite the value of education and it is effect on economic growth, women's subordinate is still a serious problem due to gender row of female children is one of the most eligible reasons for not expanding on their education. By means of investing on women education, the position of women in economic, social, cultural and political life increases (USAID, 2015).

Even though, Federal Democratic Republic of Ethiopia (FDRE) give much attention to women as central issue on PASDEP (plan for accelerated and sustained development) to end poverty to liberate woman from productivity task their participation in the labor force in social and political process of the country which include increasing woman education but situation woman in Ethiopia is much different from those many part of Africa (EPRDF, 2005).

It is widely known that education enhance labor market productivity and income growth but educating woman also has beneficial effects on measure of social well- being not measured by the market rising level of 
education. Improve women's productivity in the home which in them can increase family, health child survival and investment in children capital (Lelise, et.al, 2007).

Ethiopia is located in the horn of Africa. It is the only country of Africa that escaped western colonization. Yet today, Ethiopia remains one of the world poorest countries with the population size exceeding 100 million people, 80 percent of live on less than 2 dollar per day (Ethiopian population studies, 2008).

Ethiopia's struggle with poverty and slow development is inextricably tied to its history of conflict, current drought and environmental degradation. This situation is further complicated by deep traditional social and economic patterns that place power full constraints on the rights of women and their opportunities to direct their own lives or participate in all contribute to community and national development (FMSEsDP, 2005).

The Ethiopian government in partnership with many non- governmental organizations has targeted the needs of women in its efforts to meet the united nation millennium development goals. Although women's right are protected by the Ethiopian constitution. Male dominance remains the order of the day in both public and private spheres. Education clearly impact social benefits experience beyond the individual family. This benefit range from fostering economic growth. To extending the average life expectancy in the population and to improving the functioning of political processes (Haftu, 2004).

Although women consist half of the county's population and have high contribution to the economic development and welfare of the society they do not equally benefit from the national wealth (Tenbit, 2011). The Ethiopian education and training policy major document that aims to provide education and enables removal of attitudes, stereo types and practices that negatively affect women's education (Hareg, 2010).

The day to day lives of most Ethiopian girl students are increasingly becoming precarious. According to statistics out of 30 million women in the country only 16.7 percent are considered to be literate. Although education is open to girls, the negative social attitudes against women and educating them in particular, is still being reflected in the educational system, according to views expressed a recent meeting of women educationalist association (Yohannes Ruphael April 2015).

Micro Enterprises is needed of significance up grading in the government of Ethiopia is to be successful in the effort to eradicate poverty and to strengthen the private sector occupies a strategic position of unique importance in Ethiopian economy. Government of Ethiopia adopted a national policy on Ethiopian women with the express aim of eliminating gender and cultural basis that hinders women from participating equally in the economic and social development of the country to govern the human and democratic right. Women participation in MSEs play a crucial role in the economic important, because they utilize relatively less capital, it's a home of entrepreneur ship can create substantial job opportunity, utilize cheap and local raw materials and produce goods and services (Walelign and Wondimu, 2002).

Despite this, fact generating employment for Ethiopian women is a major challenge keeping in view insufficient opportunities in the existing formal sector. They have not only less opportunity to get education than men, but also have less employment opportunities that one of the main factors cited for migration and trafficking (Emebet, 2009). According to Reynolds (2014), one way of protecting women from manipulative situations of migration is to create job opportunities within the country, and provision of special assistance to women and MSEs.

Regarding the number of women participated in business, as per the population and housing census of Ethiopia 2007 , the total population of the county is $73,750,932$ from these $36,533,802$ are females. This accounts 49.56 $\%$ of the total population. This shows that Ethiopia is among those African countries that are known by human resource potential. But, because of different constraints the country could not utilize this human resource effectively and efficiently (Behrman J.R., and Deolalikar. A.B, 2007).

Oromia National Regional State is one of the nine regions in FDRE (Federal Democratic Republic of Ethiopia) with a large population, (constituting $35.4 \%$ of the country's population), and from those population many people's are participated in the Micro and Small Enterprises. The region has a population of 26,553,000; consisting of 13,249,999 men and 13,303,001 women, (CSA, 2005). Demographic information on Oromia region reveals that women are over $50 \%$ of the regional population. Participation of women in Micro and Small Enterprises will help to growth in productivity for this region.

Ilu Abba Bor Zone is found in Oromia region in which women have moved great steps forward in changing owns lives and their children using opportunities in place. They are now economically better, conscious and have better access to education and health service than previous days to participate in Micro and Small 
Enterprises (Semira Faris, 2013/14). This doesn't mean that the job is finished and women are equal position with men. Similarly, Mettu town is found in Ilu Abba Bor zone which is characterized by what is mentioned above. There is unequal participation of women and men in Micro and Small Enterprises.

1.2. Statement of the problem. Women's in Ethiopia have been subjected to various forms of gender based discriminations. Under traditional customary rules and practices which may have impacts on economic, political and social status of women's in the country (Sen, 2013). Women constitute more than half of the population of Ethiopia. But their environment rate and their involvement in education and participation of them in Micro \& Small Enterprises is very low when compared with males. This is because of cultural and social -economic factor. However, any effort made without recognition of women participation without bring the expected result in terms of production growth and development (Konjit, 2011).

Education is corner stone of women empowerment, because it enables them to respond to opportunities. To challenge their traditional roles and to change their lives despite the clear advantage of female education, parents tend to prefer to educate their male children. Across role in life is perceived solely as a link to the house hold and thus formal education of females may be seen as waste of resources Selamawit (2016). Education of women is one of the most cost effective means of improving structural challenges. Studies by UN, WB and other agencies have concluded that the social benefit alone of increased education of girls more than sufficient to cover its cost. Even before considering the added earning power this education brings. Young females service considerably less education than young males in almost every developing county. Women's enrolment in primary and secondary education is lower than that are men by at least $10 \%$. This educational gender gap is the greatest in poorest countries of our continent (Todaro, 2002).

Ethiopia is one of the developing countries where the Small-scale Enterprises are estimated to employ 1.5 million people. Out of these 1.5 million people that engage in Small-scale Enterprises the proportion of women is high as Small-scale Enterprises are an important source of livelihood for women in Ethiopia (Reta, 2013). In studying the involvement of women in Small-scale Enterprises, the survey conducted by the CSA in 2004 covering 48 towns indicated that 65 per cent of the informal sector activities are owned and run by women. Women have relived their fair share of the national wealth. And also it is hard fact to widen the access of woman to education training other services and also to narrows the gender gap in education.

Ethiopian Women in MSEs have faced different difficulties when they run their business. The major factors the researcher has used in this study are the following:

Access to finance: it is a key issue for women. Accessing credit, mainly for starting an Enterprises, is one of the major constraints faced by women. They often have fewer opportunities than men to gain credit for different reasons, including lack of collateral, an unwillingness to accept household assets as collateral and negative perceptions for female business owners by loan officers (Mahbub, 2010).

Lack of infrastructural facilities: The availability of a well-established, well-maintained infrastructure plays a key role in the smooth operation of an Enterprises and might ultimately affect whether it succeeds or not. In order to operate, Enterprises need roads for transportation, sanitation, water, electricity...etc. Hence, the unavailability of such facilities poses a serious obstacle in efficient operation of an Enterprises. Larger firms with better access to finance are more capable of being situated in territories characterized by more developed infrastructural services, hence the less ability of female to access such facilities imposed a serious problem on them. Finally, the social immobility of women might play an important role in hindering them from relocating their Enterprises to regions better equipped in terms of infrastructure. Poor infrastructure is a challenge, including during the rainy seasons when women in MSEs had little protection from rain or choking sun during hot seasons (Jagero \&Kushoka , 2011).

Access to land for business premises (for production and marketing): this is one of the major constraints for businesses of all sizes. Especially for women it is a major problem and it has caused women to operate from their houses or on the streets with poor sanitary conditions and exposed to theft and harassment by the police and clients. The availability of plots of land and premises in strategic areas for MSEs to produce and market their product is essential (Solomon, 2010).

In spite of the fact that women were not equally encouraged to participate in a paid work as much as male were in the past currently the interest of women to be involved the work place is increasing from time to time because of several reasons like good infrastructure made by conducive policies for work, good social networks. 
Even if there are favorable conditions for increasing school enrolment due to commitment of government toward improving education opportunities to improvement is still benefiting male more than girl (Adebayo, 2009; Egbuna, 2011).

Therefore, this study is different from the researches done before those discussed above by focus area. This study is specifically emphasized on investigating the participation of educated women in Micro \& Small Enterprises in case of Mettu town.

\subsection{Objective of the study}

\subsubsection{General Objective}

General objective of this study is to investigate the participation of educated women in Micro \& Small Enterprises in case of Mettu town.

\subsubsection{Specific objectives}

The specific objectives of this study are:

$>$ To assess the participation rate of female in relation with their male counterparts in MSEs.

$>$ To assess the role of education of women in Micro \&Small Enterprises.

$>$ To identify the policy recommendation.

\subsection{Research question}

This study consists of the following research questions:

$>$ Why the participation of women in Micro \& Small Enterprises is comparatively low with their male counter parts?

$>$ What is the role of education of women for their participation in Micro \& Small Enterprises?

$>$ What type of policy is needed for women educations to aid MSEs?

\subsection{Significance of the Study}

The study was conducted and designed to give an overall view about an educated women participation in Micro and Small Enterprises in Mettu town. This study has significant contribution in providing information for responsible bodies by recommending possible solutions by initiating for further study in the area, can solve the problem, and would bring change. Also the study would be used as a reference for further study.

\subsection{Scope of the study}

The scope of this study was limited to the participation of educated women in Micro and Small Enterprises in Mettu town. The study would examine the activities under taken by current government to empower educated women to participate in Micro and Small Enterprises. The scope of this study also limited to identify many problems of women education and their participation in Micro \& Small Enterprises in Mettu town by using both primary and secondary data.

\section{Literature Review}

\subsection{Theoritical Literature Review}

\subsubsection{Concepts and Definition}

Education has been a central focus of women seeking to improve their conditions and to raise their status for Enterprises. Education imparts skill that created options for the individual in economic, social and political life. It is an instrument for attaining high status positions. Education earns experts. The education system is also one of the most important institutional components of gender system. Education can mobilize the respect fullness of women to contribute most effectively though their surroundings. Therefore, women should be fully involved in human resource development (Gender library, 2007).

Women are central core to development process. In Africa they comprise over 50\% of adult's population which is the same as that of Ethiopia produce $90 \%$ of food processing, raise children and maintain the house hold (Suguna 2006). 


\subsubsection{Definition of Education}

Education is an investment in human capital and social development and serve as route for the transmission of culture from one generation to another and it consist of element as presentation, innovation and replacement of harm full tradition by use full ones (International encyclopedia of the social science, 1967).

Hegels logic is a search for the external forms of reason, this philosophy of nature is attempted to trade those abiding forms internal process of manifestation. Hence all forms of social life all hum institution each their educational values remind educations.

On the other hand, houses (2003) through argues that there are three important destination of education being carried on independently of one another but that in all education three factor need to be taken into account

A. The internal impulse to growth which ascertains determinate direction depending on the original nature of child.

B. Shaping the influences of physical environment making it self-sufficient through personal experience

C. The modification of the child national by means of leaching with the view to social leads. Additionally, he defined education as learning of adoption to environment lacks theory of language he also defined education on his through written in 2003 as natural and universal function of society that many generations reading are divided into six categories.

\subsubsection{Education and Economy}

Education is an investment that has certain economy return and titled with traditional economic variable. There are difficulties in attempting to see the relationship of education to the economy. These are:

1. The improbability of adequately measuring the external economic of education.

2. The fact superior income of educated person especially in under developed country may be and often is due to traditional class and case to influence for monopolistic controls with the educated class may have varies fields of production.

3. The possibility that the economic advantage of education portion of the population is due to an intrinsic superiority. Education has consumption side as well as an investment component. The consumption aspect of education unfortunately least than in the advanced countries, whereas consumption aspect of education can be born more easily (Benson, 2003)

\subsubsection{Education and its Economic Value}

Education has an economic value to cultivate and to discover potential talents. The capabilities of children and matured students can never know until they have been known as cultivated. Schooling increases the capability of people to adjust changes in job opportunism associated with economic growth. Schooling in this connection is valuable because it is a source of flexibility in making occupational and adjustments (Todaro, 2002).

\subsubsection{Investment in Female Education}

Female's education has high social rates of return. It is widely claimed that educated women many later. Want fever children and are more likely to use effective method of contraception. The move educated the mother to the lower is material mortality and healthier is the child. It is educated that child mortality fails by about $8 \%$ for each additional year of parental schooling for at least first eight to ten year of schooling (Tenbit, 2011).

\subsubsection{Why Female's Education is Important}

Young female receives less education than males in almost all poor countries. So closing the educational gender gap by expanding educational opportunities for women is economically desirable for four reasons:

1. The rate of returns on women's education is higher than that of men's in most developing countries.

2. Increasing women's education not only increase their productivity on the farm and in the factory but also results in great Labor force participation, latter marriage, lower fertility and greatly improved child health and nutrition. 
3. Improved child health and nutrition and more educated mothers lead to multiplier effect on the quality of a nation's human resource for many generations to come.

4. Because women carry all proportionate burden of the poverty and hand lessens that per male developing societies. Any significant improvement in their role and status via education can have an important impact on breaking the victim's cycle of poverty and in adequate schooling (ibid).

Education has enormous importance both creating skills and in guiding people. Whatever their talents into their most productive roles education help human being to discover and utilize materials and resource that previous generation did not appreciate improvement in efficiency include large category of potentialities variously described as technology, innovation, improvement, in equality of labor force and education itself (Benson, 2003).

\subsubsection{Education and Economic Development}

In the process of economic development an important shift revolves around education. It has a permanent place in the economist on human capital and modernization progress. Since the private financial return of education is quite substantial. The fundamental contribution of education on economic growth is to increase the level of skill, talents, knowledge and experience of people to be more enabled in the work force (The united nation university, 2012).

\subsubsection{The need for Gender Analysis in Education}

There are many reasons that we need gender analysis in education some of which are:

1. Gender equity is the priority for all development practitioners

2. Including between sexes. However, the reality show that are discriminated against boys, for example, an even distribution in all levels of education.

3. Enrollment level of girls is lower than boy and the gap is being increased in many counties and high dropout level.

4. The level of literacy rate is too low for girls.

\subsubsection{Demand for Education}

Research into the constraints to girls schooling explains the persistence of gender gaps.Girls in poor house hold are particularly likely miss out on schooling because of the perceived and actual opportunity cost (Oxaal, 2001).

\subsubsection{Opportunity costs of girls schooling}

The opportunity costs of girls schooling are high for poor households in developing countries and often exceeds the opportunity costs of boys schooling. Opportunity costs include lost choice.

The cost of education to households affects both the enrollment and dropout rates. Even when girls are attending school they are still required to help with household's choices. Which hamper their achievement in school and thus their possibility of continuity in education unforeseen incidents such as the illness of a house hold member can mean the daughters are required to drop out of school (ibid).

\subsubsection{The Ethiopian context}

Ethiopia is patriarchal society that keeps women in subordinate position. There is believed that women are choice submissive. Patient and tolerant of monotonous work and violence for which culture is used as justification. The socialization process which determines gender is partly responsible for the subjugation of women in the country. Ethiopia society is socialized in such a way that girls are held inferior to boy. In the process of upbringing boys are expected to learn and became self-reliant, major bread winner and responsible in different activity will girls are brought up to conform be obedient and dependent and specialize in door activities like cooking, washing clothes, fetching water, earning for children (Ethiopian society of populations studies, 2008).

Low education level is one of the causes and consequences of female's low socio economic status in spite the fact that significant progress has been realized in girl's education during the decade gender gap is still observed. According to various statistical abstract of the MOE the share of female students has increased from $21 \%$ to $25 \%$ between the year 1998/99 and 2002/2003. 
Though Gender Enrollment Rate (GER) in primary education has increased from 45\% in 1999 (2007 54\% in $2002 / 2003$ ) the respective figures for males are $61 \% \& 75 \%$ the gender gap is clearly observed when the Gender Parity Index (GPI). The ratio of female enrollment is considered (ibid).

\subsubsection{Women in Ethiopia}

From her birth an Ethiopian female most families are lower status and command title respect relative to her brothers and male counter parts as soon as she is able starts carrying for younger siblings helps in food preparation and spends long hours hailing water and fetching fire wood.

Low status characterized virtually every aspect of girls and women's lives. Given the heavy work load imposed on girls on the early age. Early marriage without choice and subservient role to both husband $\&$ matter in low girl and women left with view opportunity to make and act on their own decision (WNDER, 2007).

\subsubsection{Women Education in Ethiopia}

Data from ministry of education reveals that women are less represented in education. At all level specially at secondary and tertiary level. Women's is also disadvantage in the work place. This include low level of education in rural areas in adequate health care facilities, harm full traditional practice and lack of appropriate nutrition because of poverty and culture and socially condoned violence against women (ibid).

The survey conducted by the central statistical authority (CSA, 2005) showed that women account for less than half $43 \%$ of the total employees in country considering the percentage of female employees from the total number of employers by employment type. The height was the domestic activities. (78\%) and followed by unpaid activities (19.1\%). In other types of formal enrollment, the percentage of female worker is less than thirty-five $(35 \%)$. On the other hand, the survey should over represent of working men in the informal sector was $37.7 \%$ (ibid)

\subsection{Emperical Literature Review}

\subsubsection{Evidence from Micro studies}

A growing body of literature examines the benefits of educating women in developing countries. The target bodies of empirical evidence focus on the benefit experienced in formal labor market in the form of better employment opportunities and higher earnings. But women earn on average less than men in labor market. There is evidence that on the margin the returns to education are equally as high for women as for men. Benefit from education extends beyond returns to market activities. On balance market returns appear relatively more important for women than for men. Benefit of women education for family health is realized through several passes ways(Barakat, 2008).

More educated mother may be more informed about proper engine and healthy diet may have greater appreciation for health care personally give and many have greater access to information about health is though reduced fertility which intern can increase the family resources decided to each child. The education of wife has been found to have a larger effect in reducing fertility by almost three times than husband's education (Betata,2004).

\subsubsection{Empowering women}

Empowerment involves opportunities for decision making and capacity to shape. The choices of individual make or their serves, looking varies at the perspective from which empowerment is viewed it can be said that it involves access to resources such as education and finance, the opportunity to use services available in social. For example, schools, health, facilities, and other infrastructures and the opportunity to participate in decision making on matters of importance to one self and the society (Wilder, 2007).

\subsubsection{Empowerment in the Context of Development}

One of empowerment women with context of development is economic empowerment which is a process by which women are able to participate in productive activities. Earn income and loan take decision regarding their income. Various nongovernmental organization have project whose aims to create opportunity for women's economic credit schemes or establishment of project that have income generating components (ILO,2014). 
Another aspect of women empowerment in development is political empowerment which could be achieved through the promotion of participation of women in politics at varies levels this need to be accompanied by attempts to democratize the whole system and encourage the development of civil society. In this regard various institutions could help by supporting women's involvement in government as well as in national \& local party politics in nongovernmental organization and various other women's organization (ibid).

\subsubsection{Women and Environment}

One of important issues in the current development gender is environment. The limited number of resources environmental degradation and pollution environment has become attention grabbing problems. Deterioration of natural resource displaces communities, which makes women carry the heavy burden of keeping the family together. At the same time women have significant influence on their environment since they manage and use natural resources in the process of providing sustenance to their families and communities as recognized on the united nations conference on environment in 1988 (Tenbit, 2011).

\subsubsection{Barriers to Female Education}

The barriers to girls' education may be found in the home, at school, in market place and in society at large. Gender in equality begins with girls' socialization that women should devote themselves primarily to their husband and children, not to employment in the labor market. Education is encouraged if it improves marriage prospect of Girls often have higher reputation and dropout rates than boys for many reasons, House hold responsibilities, child labor, higher opportunity cost of the family, sexual harassment and violence in school and in route to school.

Lack of girl friendly facilities particularly serious problem during menstruation and gender based discriminatory teaching and learning method of parent and community who are not aware of the value of education for girls.

The following can also be additional factor affecting women education like, shortage of female literacy workers, lack of support from husband, who do not see relevance of their wives being literate in sufficient motivation of interest. Women have neither time nor energy cost for education activities (Hill, 2006).

\section{Reaserch Methodology}

\subsection{Description of the Study Area}

The study was conducted in Oromia regional state Illubabor zone at Mettu town. Mettu town is a market town and separate woreda along Sor River located in southwestern part of Ethiopia at the distance of $600 \mathrm{kms}$ from the capital city of Ethiopia, Addis Ababa. Mettu is capital city of Illu Aba Bora zone which was established in 1905. It's bordered on the south by Becho woreda, on the southwest by Bure, on the west by the Ale woreda, on the north by the Nopha woreda, on the east by Hurumu woreda. The average annual rainfall of this town is $1701 \mathrm{~mm}$. The average annual temperature is $19.90 \mathrm{c}$. Its astronomical location is $8^{\circ} 31^{\prime} 11^{\prime \prime}$ North Latitude and $29^{\circ} 57^{\prime} 41^{\prime \prime}$ East Longitude. Mettu has been an important market of the coffee trade, with several foreigners residing town as early as the 1930s to buy the crops from local farmers. At this early date, the town was connected by telephone to Gore and Addis Ababa. The city also has a high school and hospital. Mettu is one of the reform towns in the region and has a town administration, Municipality and three kebeles. Mettu town has total population of 97,260 of whom 48,430 are men and 48,830are women. The total area of land in this town is 68,723 hectares (Mettu administration office, 2019).

\subsection{Data Type and Source}

To investigate this study data would be obtained from both primary and secondary data sources. The primary data is gathered by using structured questionnaires, interviews and observations, whereas the secondary data source is collected from different written documents, such as books, magazines and other related materials. The primary data would be qualitatively collected from individual person and whereas the secondary data would be quantitatively collected from written documents.

\subsection{Method of Data collection}

The primary data was gathered by: questionnaires and observation, whereas the secondary data source was collected from different written documents, such as letters, books, magazines and other related materials. The primary data would be qualitatively collected from the individual person and whereas the secondary data would be quantitatively collected from written documents. The researcher was gathered questionnaires and interview 
while conducting the research. The researcher was prepared both close ended and open ended questionnaires and personal interviews.

\subsubsection{Method of sampling technique}

The sampling technique that a researcher was use out of four kinds of probability sampling methods, simple random sampling would be employed; because this method of data collection is simple and avoids the probability of making personal bias. It was easier for the researcher to administer and number of the unit is simple for a given cost.

\subsubsection{Sample size determination}

Since it was difficult to collect the necessary data from the whole population that engaged in MSEs in the Mettu town, the total number of women in MSEs in the town are 316 in the five MSEs ( urban agriculture, service sector, trade sector, construction and manufacturing), (Mettu town public service and MSEs Agency Office 2019). Due to this the researcher uses 56 clients as a sample size, which are full representative of the total population obtained based on the following formula, which is developed by Kohtari, (2004) to determine the required sample size at $90 \%$ confidence level $=0.9$, to take a $10 \%$ level of precision $=0.1$.

$\mathrm{n}=\mathrm{z}^{2} \mathrm{pqN} / \mathrm{e}^{2}(\mathrm{~N}-1)+\mathrm{z}^{2} \mathrm{pq}$

Where: $\mathrm{n}$ is the sample size, $\mathrm{N}$, is population size and $\mathrm{e}$ is the level of precision, $\mathrm{z}$, from table using confidence level, p, probability to be selected, q, probability not to be selected. Based on the above formula the study was carried out on 56 respondents.

The population of study was the total number of participation of educated women in Micro and Small Enterprises in case of Mettu town.

Sample size include from MSEs:

According to Mettu town in Micro and Small Enterprises 258 is number of MSEs, total number of educated women are 316 from the total 316 (56 respondents are selected for the sample size determination).

So, $\mathrm{n}=(1.64)^{2}(0.5)(0.5) * 316 /(0.1)^{2}(316-1)+(1.64)^{2}(0.5 * 0.5)$

$=(2.6896) *(0.25) * 316 /(0.01) *(315)+(2.6896) * 0.25=212.4784 / 3.8224=55.59=56$ rounded

\subsection{Method of Data Analysis}

After the necessary data for the study are collected, the processing and analysis of the data would be under taken. Data processing is to make raw data suitable for further analysis editing and classification was made. Editing is process of examination of collected data. In order to sure possible problem were resolved the data analysis would be organized by using table and percentage to put part of the descriptive data.

\section{Data Analysis and Inter Pretation}

The general purpose of the study was to assess the Participation of educated women's in Micro \& Small Enterprises of Mettu town. In doing, so questionnaire that consists of 25 items was prepared. The data gathered were presented and interpreted one after another. All the data presented, analyzed and interpreted are obtained from questionnaires. The questionnaires are yield by Mettu town Micro \& Small Enterprises. These questions were divided into five parts as it is shown on the back of the paper.

The first part which consists of five questions, designed to assess the demographic information of respondents of participation of educated women's in Micro \&Small Enterprises. The second parts were which consist of six questions designed to know the participation of educated women's in Micro\& Small Enterprises and the third part consisted five questions to know the presence and importance of training and orientation program of MSEs. However, fourth parts and fifth parts has 6 and 3 questions respectively, to assess the social, economical, political and legal condition of the country in part five and financial assessment of MSEs sectors in part six.

The questionnaires were organized based on the sequences which were provided in the questionnaire. A total of 56 respondents were taken to fill the questionnaires. Among 56 questionnaires distributed only 6 were not collected these means 50 respondents were properly filled the questionnaires. 


\subsubsection{Demographic information of respondents}

\subsubsection{Sex Composition}

The following table shows data collected from Mettu town MSEs, which indicates the demographic information of respondents.

Table 1. Sex composition of educated women

\begin{tabular}{|l|c|c|}
\hline Sex & No & Percentage \\
\hline Male & 35 & 62.5 \\
\hline Female & 21 & 37.5 \\
\hline Total & 56 & 100 \\
\hline
\end{tabular}

Source: Household Primary Survey, 2019.

From the above tables it's possible to interpret that the number of participants who take part in MSEs males are more than females. The number of males is $35(62.5 \%)$ and the number of females are $21(37.5 \%)$ this indicates that males have more participation in MSEs than females.

\subsubsection{Age Composition}

The following table shows the age composition of respondents gathered through questionnaires.

Table 2. Age composition of educated women

\begin{tabular}{|c|c|c|}
\hline Age group & No & Percentage \\
\hline$<20$ & 20 & 35.71 \\
\hline $20-25$ & 27 & 48.21 \\
\hline$>25$ & 9 & 16.072 \\
\hline Total & 56 & 100 \\
\hline
\end{tabular}

Source: Household Primary Survey, 2019.

The above table reveals that the most employees or operators of the selected MSEs are between 20-25 age which contains $48.21 \%$ followed by less than 20 which counts $35.71 \%$ of the respondents. This again confirm that the sector created job opportunities for women who are in the energetic productive age. This helps to the town to improve the living standard of the peoples in the sector and also encourage it the participation of educated women in MSEs.

\subsubsection{Educational status}

Education has a positive effect on economic growth and poverty reduction. In other words education and economic developments are directly related to each other (Todaro,2003). Engagement in Micro and Small Enterprises does not specify people in educational level. it allows both educated and uneducated to take part in running it and improving their life standards. The following table shows the collected data from targeted group in relation to their educational level.

The questionnaires included information on educational level of the respondents to identify the skill of the respondents based on their level of education. Understanding the level of respondents educations helps in identifying and determining the development approaches to be followed (Akililu, 2010).

Table 4. 1.3. Educational level of women's whom they are participated in MSEs

\begin{tabular}{|l|c|c|}
\hline \multicolumn{1}{|c|}{ Items } & Number & Percentage \\
\hline Illiterate & 5 & 8.93 \\
\hline Elementary school & 11 & 19.64 \\
\hline High school & 22 & 39.29 \\
\hline Preparatory school & 12 & 21.43 \\
\hline Other & 6 & 10.71 \\
\hline Total & 56 & 100 \\
\hline
\end{tabular}

Source: Household Primary Survey, 2019.

As it is indicated in the above table $8.93 \%$ of respondents are illiterate, $19.64 \%$ are elementary school attended, $39.29 \%$ are high school attended, $21.43 \%$ are preparatory school attended and $10.71 \%$ are other such as, level I, level II, diploma and first degree holder. This conveys that most of the participants are skilled women. It's possible to know that most of them were unemployed before joining this sector. 
Most of the women's who they are participated in MSEs educational level is high in high school level 20 ( $39.29 \%$ ) and in another level like, degree, diploma and 10+2 technical training are low $6(10.71 \%)$ Therefore the highest level of educated women whom they are participated in MSEs was skilled at high school level.

\subsubsection{Martial status of respondents}

The sectors opens opportunity for every person who is willing and able to participate in it. It is not limited to specific groups of people. The marital status of respondents is presented in the following table.

Table 4.1.4 Martial status

\begin{tabular}{|l|c|c|}
\hline \multicolumn{1}{|c|}{ Items } & Number & Percentage \\
\hline Single & 10 & 17.86 \\
\hline Married & 32 & 57.14 \\
\hline Divorced & 8 & 14.29 \\
\hline Widowed & 6 & 10.71 \\
\hline Total & 56 & 100 \\
\hline
\end{tabular}

Source: Household Primary Survey, 2019.

As it shown as in the above table out of the 56 respondents in the selecting Enterprises $10(17.86 \%)$ are single while, $32(57.14 \%)$ are married. The divorced and widowed sample respondents accounted for about 8 $(14.29 \%)$ and $6(10.71 \%)$ respectively. Hence, the table shows that most of single and married women are able to participate in MSEs that means not mean that divorced and widowed are not participate. The sector is capable to absorbing all individuals without indiscriminately and increasing their income, remove unemployment and also reduce income inequalities among the people via efficient allocation of available resources.

\subsubsection{Participation of educated women in Micro \& Small Enterprises}

\section{1.2.1. Information about MSEs}

The table below indicated that the information of an educated women whom they are participated in Micro and Small Enterprises.

Table 4.2.1 Familiarity with MSEs

\begin{tabular}{|l|c|c|}
\hline \multicolumn{1}{|c|}{ Items } & Number & Percentage \\
\hline Yes & 39 & 69.64 \\
\hline No & 17 & 30.36 \\
\hline Total & 56 & 100 \\
\hline
\end{tabular}

Source: Household Primary Survey, 2019.

The table above indicates that the most of educated women are familiar with the terminology of MSEs; approximately, out of 56 respondents there are 39 (69.64\%) respondents are familiar with the concept of MicroSmall Enterprises (MSEs). However, only 17 (30.36\%) respondents were not even familiar with the terminology of MSEs.

\section{1.2.2. MSES Traits}

The following table indicates that the responses of an educated women on MSEs traits.

Table 4.2.2. Responses on the MSEs traits

\begin{tabular}{|l|c|c|}
\hline \multicolumn{1}{|c|}{ Items } & Number & \multicolumn{2}{c|}{ Percentage } \\
\hline Low & 7 & 12.2 \\
\hline Very low & 5 & 9.2 \\
\hline High & 20 & 35.72 \\
\hline Very high & 24 & 42.86 \\
\hline Total & 56 & 100 \\
\hline
\end{tabular}

Source: Household Primary Survey, 2019.

That was the highest number of educated women were very high responses in MSEs, which consists of $42.86 \%$ (24), and only $9.2 \%$ (5) were very low. These explained most of educated women have very high responses on MSEs traits. 


\section{1.2.1. Training Programme}

The following table shows the availability of training programme on MSEs for educated women.

Table 3. The participation in MSEs Training program

\begin{tabular}{|l|c|c|}
\hline \multicolumn{1}{|c|}{ Items } & Number & Percentage \\
\hline Yes & 47 & 83.93 \\
\hline No & 9 & 16.07 \\
\hline Total & 56 & 100 \\
\hline
\end{tabular}

Source: Household Primary Survey, 2019.

Most of educated women were believed as the participation in MSEs training program provides enough knowledge to start MSEs as explained in table 4.2.3 above, 47 (83.93\%) are responses yes but few of them were responses no $9(16.07 \%)$. This indicates that participation in Micro Small Enterprises are necessary to those who involved in the sector.

\subsubsection{Interests of educated women in MSEs.}

The table below indicted that the interests of educated women to participate in Micro and Small Enterprises.

Table 4. Interest of women in Small \& Micro Enterprises

\begin{tabular}{|l|c|c|}
\hline \multirow{2}{*}{ Item } & No & Educated Women \\
\cline { 2 - 3 } & 30 & Percentage \\
\hline Most interested & 18 & 53.57 \\
\hline More interested & 8 & 32.14 \\
\hline Less interested & 56 & 14.29 \\
\hline Total & 100 \\
\hline
\end{tabular}

Source: Household Primary Survey, 2019.

As described in the above table to measure the Micro Enterprises it adopts scale to measure all items on those points with the levels most interested, more interested and less interested. 30 (53.57\%) of Micro and Small Enterprises of woman responded most interested and less interested with each percentage of $18(32.14 \%)$ and $8(14.29 \%)$ respectively. It implies that the majority of women is higher in starting new Enterprises. It also show that educated women's are more interested in starting their own Micro Enterprises that is why educated have their knowledge (access to start new Micro \& Small Enterprises). Generally, most of educated woman's recognized as important for setting up Micro \& Small Enterprises.

\subsubsection{Respondents reason for joining MSEs.}

All individual businessmen have his/her own reason or motivation why he or she joined business. As survey shows depending up on collected data, respondents joined the Enterprises for different reason but the time they joined the sector at different times. The following table mentions the main reasons why they joined the sector.

Table 5. Reasons that motivates educated women to setup MSES

\begin{tabular}{|l|c|c|}
\hline \multirow{2}{*}{ Items } & \multicolumn{2}{c|}{ Educated women } \\
\cline { 2 - 3 } & \multicolumn{2}{c|}{ Number } \\
\hline No job & 7 & Percentage \\
\hline Preference to be entrepreneur & 28 & 12.5 \\
\hline Family back ground & 15 & 50 \\
\hline Enforced by other & 6 & 26.79 \\
\hline Total & 56 & 10.71 \\
\hline
\end{tabular}

Source: Household Primary Survey, 2019.

Most of educated women whom they are participated in MSEs are motivated to start own MSEs to become an entrepreneur $28(50 \%)$. No job 7 (12.5\%), family background $15(26.79 \%)$ and some are enforced by others 6 (10.71\%). Therefore the most cases enforced women's their own MSEs was to become an entrepreneur. This indicated that women have the willingness to become an Entrepreneur and mostly participated in MSEs.

\subsubsection{Source of MSES}

All the job opportunity needs knowledge how to make good result in its kind. Therefore participation in MSEs needs good knowledge to perform useful and fruitful results for whom those participants in it.

The table below indicates the source of knowledge of educated women in MSES. 
Table 6. Sources of Micro \& Small Enterprises of educated women

\begin{tabular}{|c|c|c|c|}
\hline \multirow[t]{2}{*}{ Item } & \multirow[t]{2}{*}{ Responses } & \multicolumn{2}{|c|}{ Educated Women's } \\
\hline & & Number & Percentage \\
\hline \multirow{2}{*}{$\begin{array}{l}\text { Do you have enough knowledge about Micro \& } \\
\text { Small enter price? }\end{array}$} & Yes & 42 & 75 \\
\hline & No & 14 & 25 \\
\hline \multirow[t]{5}{*}{ From where you have got? } & Education & 30 & 53.57 \\
\hline & Tasked with (MSE)person & 15 & 26.79 \\
\hline & Experience from parents & 10 & 17.89 \\
\hline & None & 1 & 1.79 \\
\hline & Total & 56 & 100 \\
\hline
\end{tabular}

Source: Household Primary Survey, 2019.

Women were asked whether they have enough knowledge about Micro \& Small Enterprises or not. As it has shown in the table above $42(75 \%)$ of MSEs only $25 \%$ of them responded as they do not have enough knowledge about the sector. This indicated that most of the women's whom they are participated in MSEs have a knowledge.

\section{Source of Micro \& Small Enterprises knowledge of educated women}

As depicted in the above table $30(53.57 \%)$ women responded that they have got their Micro Small Enterprises knowledge from education $15(26.79 \%)$, tasked with another person and experience from parents $10(17.89 \%)$ and none $1(1.79 \%)$ respectively, of women have got from neither of the above sources.

\subsubsection{Micro \& Small Enterprises vision of women's}

When asked in principle of woman do ever they have a vision of self -running their own Micro Enterprises, they responded as follows:

Table 7. Micro \&Small Enterprises vision of woman

\begin{tabular}{|l|c|c|}
\hline \multirow{2}{*}{ Item } & \multicolumn{2}{|c|}{ Educated Women's } \\
\cline { 2 - 3 } & Number & Percentage \\
\hline Yes certainly & 28 & 50 \\
\hline May be & 22 & 39.29 \\
\hline No & 2 & 3.57 \\
\hline Already in (MSE) & 4 & 7.14 \\
\hline Total & 56 & 100 \\
\hline
\end{tabular}

Source: Household Primary Survey, 2019.

Over $50 \%$ of educated women in the Micro \& Small Enterprises would consider in to (MSE) for themselves. This indicates that majority of Micro \& Small Enterprises women are in vision of going into running (MSE) themselves.

\subsubsection{MSEs Sectors}

The table below explores that the sectors which are selected in the educated women participated. This table identifies the frequency and percentages of women in MSEs in each sectors.

Table 8. MSEs Sectors and women participated

\begin{tabular}{|l|c|c|}
\hline \multirow{2}{*}{\multicolumn{1}{|c|}{ Items }} & \multicolumn{2}{c|}{ Educated women's } \\
\cline { 2 - 3 } & Number & Percentage \\
\hline Urban agri. & 5 & 8.93 \\
\hline Service sector & 23 & 41.07 \\
\hline Trade sector & 18 & 32.14 \\
\hline Construction & 7 & 12.5 \\
\hline Manufacturing & 3 & 5.36 \\
\hline Total & 56 & 100 \\
\hline
\end{tabular}

Source: Household Primary Survey, 2019

The most developed among Micro \&Small Enterprises by participating women was service sector. 23 $(41.07 \%)$ for the two most developed Micro \& Small Enterprises more than 25\% \& of respondents obtained high scores. It implies that most of women have the service and trade sectors. In the trade sector 18 (32.14\%) of educated women's are involved.

From the above Table 8 the least scored Micro \&Small Enterprises were arranged from lowest to highest as follows: 
$>\quad$ Manufacturing sector scored total $3(5.36 \%)$

$>\quad$ Construction sector scored total $7(12.5 \%)$

Surprising manufacturing sector ranked the first from below. This shows that woman is not developed in Micro $\&$ Small Enterprises of manufacturing sector. Generally as we can see from the data most of women are developed in the service \& trade sector in contrast, manufacturing, construction and urban agriculture, they are poor in these sectors.

\subsubsection{Challenges in MSEs}

In the any kinds of job opportunity there is challenges, to work or not to work. Similarly in the MSEs. There are full of challenges. The following table below explains the challenges that faced educated women in MSEs.

Table 9. Challenges that faced educated women in MSEs

\begin{tabular}{|l|c|c|}
\hline \multirow{2}{*}{ Responses } & \multicolumn{2}{|c|}{ Educated women } \\
\cline { 2 - 3 } & Number & Percentage \\
\hline Financial problem & 29 & 51.79 \\
\hline Social problem & 11 & 19.64 \\
\hline Market related problem & 16 & 28.57 \\
\hline Total & 56 & 100 \\
\hline
\end{tabular}

Source: Household Primary Survey, 2019.

As in the above table, the all respondents agreed that there is problem in their work. As the computation result shows the challenges that faced educated women in MSEs financial problem $51.79 \%$ and the second most problem is market related problem $28.57 \%$. The social related problem faced by small percent which is $19.64 \%$.

From this we conclude that the primary problem that should be given priority is the difficulty in securing funds for the establishment and operation of the sector and difficulty of market condition (demand and supply side). However, this is not the only problem that MSEs are facing. There are also many other problems which affect their growth and expansion. As for instance, financial problems, social related problems, market problems, accessibility of training problems and etc.

\subsubsection{Family/ relatives engaged in MSES}

When asked whether there is a person in their family who works in Micro \& Small Enterprises the respondent responses as follow:

Table 10. Family/relative in Micro \&Small Enterprises

\begin{tabular}{|l|c|c|}
\hline \multirow{2}{*}{ Item } & \multicolumn{2}{|c|}{ Educated } \\
\cline { 2 - 3 } & Number & \multicolumn{2}{|c|}{ Percentage } \\
\hline Yes & 28 & 50 \\
\hline No & 28 & 50 \\
\hline Total & 56 & 100 \\
\hline
\end{tabular}

Source: Household Primary Survey, 2019.

As the above table indicates 26 (50\%) of Micro \& Small Enterprises responded' yes' and $26(50 \%)$ of them responds 'no'. This implies that having relatives or family in Micro Small Enterprises does equally enhance them to participate in MSEs according to the responses of respondents in the table 4.3.5 above.

\subsubsection{Micro \& Small Enterprises towards Social, Cultural, Economical and Political condition.}

\section{4 .1.4.1.1 Socio-Cultural Environment}

Socio - cultural factors like, work cultures, honesty, hard work, religion, language attitudes towards etc have an appreciable impact for those who want to start Micro \&Small Enterprises when asked about culturalcondition in the environment.

Table 11. Cultural environment

\begin{tabular}{|l|c|c|}
\hline \multicolumn{1}{|c|}{ Items } & No & Percentage \\
\hline Yes & 35 & 62.5 \\
\hline No & 21 & 37.5 \\
\hline Total & 56 & 100 \\
\hline
\end{tabular}

Source: Household Primary Survey, 2019. 
In the above table it has been shown that 21 (37.5\%) of respondents described that Micro \&Small Enterprises in their environment have not been considered as a respected job.

The reasons for respondents who said 'no' are as follows:

$>\quad$ Some people believed as only job is the government official employed.

$>\quad$ Because it considered as low source of income

$>\quad$ In the society Micro Enterprises are not considered as a respected job and etc.

\subsection{4 .2 Economic - Environmental Assessment}

Most of the time political ideology of the ruling government of a country greatly shapes the economical system.

Table 12. Economic Environment Assessment

\begin{tabular}{|l|c|c|}
\hline \multicolumn{1}{|c|}{ Items } & No & Percentage \\
\hline Yes & 43 & 76.79 \\
\hline No & 13 & 23.21 \\
\hline Total & 56 & 100 \\
\hline
\end{tabular}

Source: Household Primary Survey, 2019.

In the above table it has been shows that 43 (76.79\%) of respondent described that the current Ethiopian economic policy is favorable for Micro \& Small Enterprises. Whereas the last $13(23.21 \%)$ of the respondents said that not favorable for Micro \&Small Enterprises. It indicates that the present economic environment is favorable for potential Micro \& Small Enterprises. The reasons for respondents who were disfavored of the current Ethiopian economic policy were as follows:

$>\quad$ Low (minimal) incentive for Micro \& Small Enterprises

$>\quad$ Need of high amount of interest rate from financial institutions

$>\quad$ No financial support for Entrepreneurs ( not as much as enough)

$>\quad$ High taxation and etc.

\subsubsection{An Assessment of Political-Legal Environment}

Government plays a crucial role in the different decision making areas of Micro \& Small Enterprises when asked them the political condition of the country the respondents they responded as follows:

Table 12. Political and legal Assessment

\begin{tabular}{|l|c|c|}
\hline \multicolumn{1}{|c|}{ Items } & No & Percentage \\
\hline Yes & 31 & 55.36 \\
\hline No & 25 & 44.64 \\
\hline Total & 56 & 100 \\
\hline
\end{tabular}

Source: Household Primary Survey, 2019.

As it has shown in the table above $31(55.36 \%)$ of the respondents described that political and legal condition of county were suitable for potential Micro \& Small Enterprises were as $25(44.46 \%)$ of respondents repeals that the political or legal conditions are rising in the country has not been as such suitable for potential Micro \&Small Enterprises.

The reasons for respondents who were disfavored of the political legal condition existing country are as follows:

$>\quad$ Poor policies regarding infringement, regulation regarding packaging and population rule.

$>\quad$ The complexity in permission of regulating agencies permission for a new plant and building facilities

$>\quad$ There are no shared objectives of government and private sectors.

$>\quad$ Market regulation is not mostly ensuring fair competition and market efficiency.

$>\quad$ The political situations in our country were not favorable and etc. 


\subsubsection{Financial Assessment of Educated Women in MSEs.}

The following table indicates that the source of funds for an educated women in MSEs, to facilitate their participation in the proper manner and also to made good conditions for the new entrants whom they have willingness to involve in the terminology of MSEs. The following table shows the sources of funds in the sector:

Table 13. Sources of funds for the women in MSEs

\begin{tabular}{|l|c|c|}
\hline \multirow{2}{*}{ Items } & \multicolumn{2}{c|}{ Educated women } \\
\cline { 2 - 3 } & Number & Percentage \\
\hline Bank & 15 & 26.79 \\
\hline Loan from partner & 13 & 23.21 \\
\hline Personal saving & 27 & 48.21 \\
\hline Other & 1 & 1.79 \\
\hline Total & 56 & 100 \\
\hline
\end{tabular}

Source: Household Primary Survey, 2019.

From the above table it is obviously clear that the sources of their funds were mostly from their own saving $48.21 \%$. Banks were only $26.79 \%$ and partners $23.21 \% .1 .79 \%$ of the respondents get funds from another sources such like family and etc. From the above table we can conclude that own saving is necessary to start up MSEs in the study area.

\subsubsection{Supports from government in MSEs}

In the any economic sector government support is necessary to run for the long period of time and to obtain the well necessary result. The following table below shows the financial support of government in the MSEs sectors:

Table 14. Financial support from government

\begin{tabular}{|l|c|c|}
\hline \multicolumn{1}{|c|}{ Items } & Number & Percentage \\
\hline Yes & 28 & 50 \\
\hline No & 28 & 50 \\
\hline Total & 56 & 100 \\
\hline
\end{tabular}

Source: Household Primary Survey, 2019.

As in the above table fifty- fifty percent of respondents were say 'yes' and 'no'. This implies the presence of financial support from government, to whom they are participated in MSEs of the study area. But to get this financial support from government it takes a time.

\section{Summary of Finding and Recommendation}

The main objective of this study is to investigate the participation of educated women in Micro \& Small Enterprises of Mettu town. Along with the study assess the social, economic, political and legal conditions prevailing in the country. During the study is conducting the researcher used the primary data, the targeted populations were women's in Micro \& Small Enterprises whom total numbers are 316, also their selection were 56 woman. The data were collected through questionnaires and analyzed based on qualitative and quantitative expressions.

The findings on women in Micro \& Small Enterprises should summarized as follows:

The two most developed Micro \& Small Enterprises among women were:

Service sector and Trade sector

The three least developed Micro \& Small Enterprises among women were:

$>\quad$ Manufacturing sector

Construction sector and Urban agriculture sector

My finding regarding to Micro \& Small Enterprises shows that three of the five Micro \& Small Enterprises are under investigation. With regard to the other Micro \& Small Enterprises were the finding indicates that three main works were under investigation:

1. Educational knowledge on Micro \&Small Enterprises;

2. The women attitude towards starting (MSE);

3. Creative motivation for new Micro \&Small Enterprises (MSEs).

Generally we can say that educated women developed in most of Micro \&Small Enterprises. Among the six questions prepared for (MSEs) the five question where better scored. On the other hand the finding on social, 
economic and political condition for the flourishing of (MSEs). According to the educated woman's believed, but still there are some problems which may need corrective action such as:

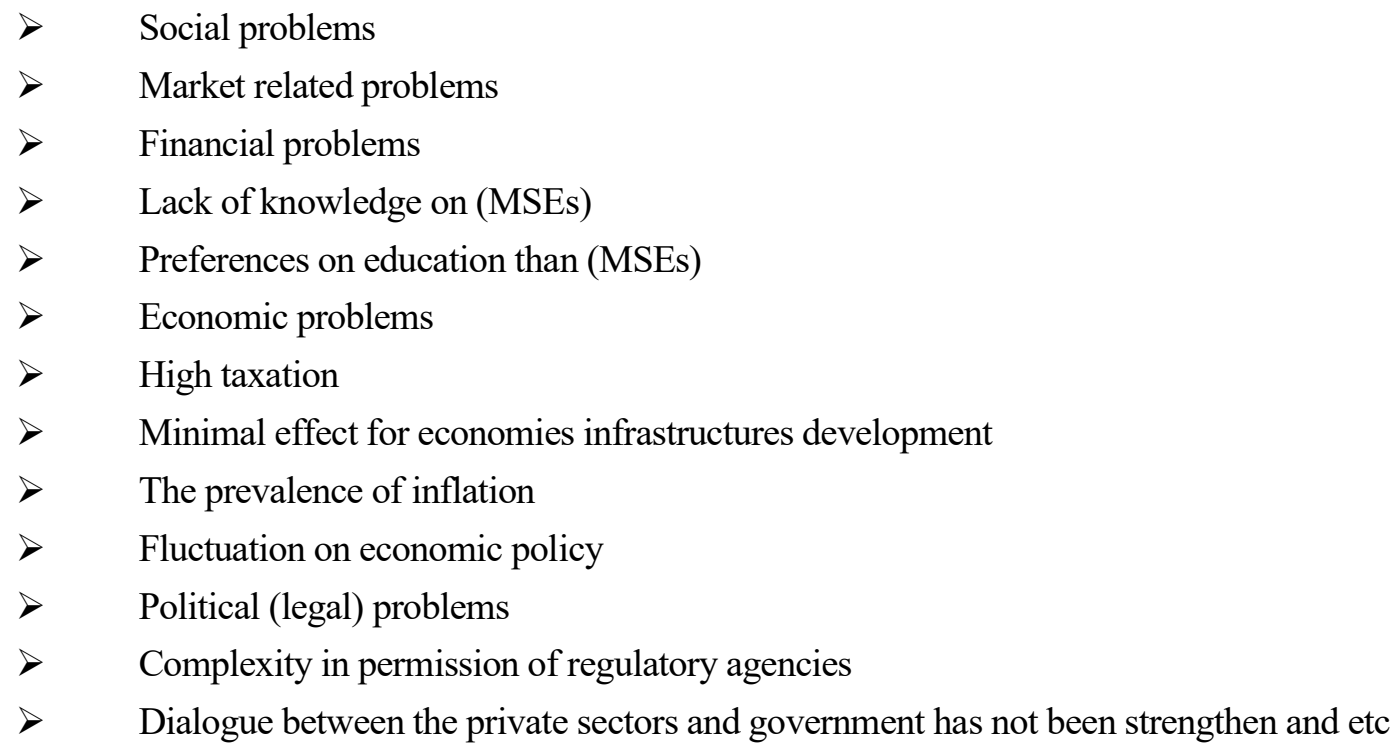

\section{Recommendation}

This research finding has important implication for all stock holders who are participated in Micro \& Small Enterprises, education and fostering Micro \& Small Enterprises ventures. It is believed that the Micro \& Small Enterprises which seen to be least developed should be addressed in responsible manner.

The following developed (MSEs) women need to be correlated and developed:

Service sector and

Trade sector

Through adopting curricula and implementation practical initiatives women can be given the opportunity to develop attention should be given to creation of learning environment where these skills are fostered and further developed.

\section{List of Abbreviations}

CSA- Central Statistical Authority

ESPS- Ethiopian Society of Population Study

FDRE- Federal Democratic Republic of Ethiopia

FMSEsDP- Federal Micro and Small Enterprises Development Package

GPI - Gender Parity Index

GER - Gender Enrollment Rate

MSEs - Micro \& Small Enterprises

MOE - Ministry of Education

PASDEP - Plan for Accelerated and Sustained Development to end Poverty

UN - United Nation

WB - World Bank

\section{References}

1. Barkat, A. (2008). Women Empowerment: a key to human development. Retrieved from: http://www.goodgovernance.org 
2. Beteta, K.C. (2006). What is Missing in Measures of Women's Empowerment? Human Development and Capabilities, 2(7), 221-241. https://doi.org/10.1080/14649880600768553

3. Benson Charles (2003). Respective on the economics of education. American educational research association USA, 38(4). 213-214.

4. Emebet Mulugeta (2009). Woman and empowerment in Ethiopia Addis Ababa, (I). 13-16. Retrieved from: http://www2.pathfinder.org/site/DocServer/PI WE paper_final.pdf?docID=10202

5. EPRDF (2005). Plan for Accelerated and Sustained Development to end poverty. Behanena Selam printing press. Addis Ababa, 2 (II). 8. Retrieved from: https://www.afdb.org/fileadmin/uploads/afdb/Documents/PolicyDocuments/Plan_for_Accelerated_and_Sustained_\%28PASDEP\%29 final_July_2007_Volume_I_3.pdf

6. Ethiopia society of population studies (2008). Gender inequality and women's empowerment. books, goggle.com et (UNFPA). Addis Ababa, 1(2). 16 -36. Retrieved from: https://www.unfpa.org/sites/default/files/pubpdf/gender-responsive.pdf

7. Gender library (2007). Woman in development priorities in Ethiopia. Retrieved from: https://www.who.int/health-topics/gender

8. Hareg consultant $\mathrm{p} / \mathrm{c}$ (2010). National action plan for gender equality in Ethiopia. Report to congress by junior officer. Addis Ababa, 18(11), 7. Retrieved from: http://extwprlegs1.fao.org/docs/pdf/eth149708.pdf

9. Hegel. (1909). Theory of education. Mackenzie; London, 32. Retrieved from: https://www.jstor.org/stable/3121731?seq=1

10. International encyclopedia of the social science (1967). Macmillan, USA, 256, 8. 879-914. https://doi.org/10.1002/ncr.4100570915 Retrieved from: https://onlinelibrary.wiley.com/doi/abs/10.1002/ ncr.4100570915

11. Jennifer and Wilder (2007). Women empowerment in Ethiopia. Addis Ababa. 4-5. Retrieved from: http://www2.pathfinder.org/site/DocServer/PI_WE paper_final.pdf?docID=10202

12. Hill, M. A. (2010). Women's education and economic well-being. Feminist Economics, 1(2), 21-46. https://doi.org/10.1080/714042230

13. Ministry of Education (2003). Educational statics annual abstract. MOE, 21 (III). 121-123. Suguna (2005). Women's Economic Empowerment Gender and Growth Literature Review and Synthesis, 43. Retrieved from: https://searchworks.stanford.edu/view/5848042

14. Todaro, M. (2002). Economic development. $8^{\text {th }}$ edition peak son London, 9(6), 240-242. http://corgihomeplan.co.uk/cgi-bin/download.php?article=economic development todaro smith 8 th edition pd f\&code $=1 \mathrm{e} 18107 \mathrm{e} 7 \mathrm{f} 201 \mathrm{bc} 2 \mathrm{e} 1 \mathrm{~d} 3 \mathrm{be} 4 \mathrm{f} 38 \mathrm{a} 30 \mathrm{cc} 3$

15. USAID (2013). United State Agency International Development.42(4), 89. https://fas.org/sgp/crs/row/R44117.pdf

16. United Nations Development Fund for Women (UNIFEW). (2015). Progress of the World's Women New York, 67. Retrieved from: https://www.unwomen.org/en/digital-library/publications/2015/4/progress-of-theworlds-women-2015

17. Mengesha, S. M. (2001). Participation of Ethiopian Women in Education and Development International Conference on African Development Archives. 23. Retrieved from: https://scholarworks.wmich.edu/cgi/viewcontent.cgi?referer=https://www.google.com/ \&httpsredir $=1 \&$ article $=1032 \&$ context $=$ africancenter icad archive

18. Worlds bank development indicators (2010). Retrieved from: https://openknowledge.worldbank.org/handle/10986/4373

19. Yohannes, R. (2015). Participation of women in education. PANA, 1(1), 1-2. Retrieved from: http://www.aau.edu.et/

20. Zoe Oxaal (2001). Education and Poverty: A Gender Analysis, Institute of Development Studies (IDS), University of Sussex, United Kingdom. 